\title{
Evaluation of groundwater quality and suitability for irrigation and drinking purposes in southwest Punjab, India using hydrochemical approach
}

\author{
Diana Anoubam Sharma ${ }^{1} \cdot$ Madhuri S. Rishi $^{1} \cdot$ Tirumalesh Keesari $^{2}$ (D)
}

Received: 6 June 2016/ Accepted: 29 July 2016/Published online: 26 August 2016

(C) The Author(s) 2016. This article is published with open access at Springerlink.com

\begin{abstract}
Groundwater samples from alluvial aquifers of Bathinda district, southwest Punjab were measured for physicochemical parameters as well as major ion chemistry to evaluate the groundwater suitability for drinking and irrigation purposes and to present the current hydrochemical status of groundwater of this district. Temporal variations were analyzed by comparing the pre- and postmonsoon groundwater chemistry. Most of the samples showed contamination: $\mathrm{F}^{-}(72 \%), \mathrm{Mg}^{2+}(22 \%), \mathrm{SO}_{4}{ }^{2-}$ (28\%), TH $(25 \%), \mathrm{NO}_{3}{ }^{-}(22 \%), \mathrm{HCO}_{3}{ }^{-}(22 \%)$ and TDS $(11 \%)$ during pre-monsoon and $\mathrm{F}^{-}(50 \%), \mathrm{Mg}^{2+}$ (39\%), $\mathrm{SO}_{4}{ }^{2-}(22 \%), \mathrm{TH}(28 \%), \mathrm{NO}_{3}{ }^{-}(22 \%)$ and TDS (28\%) during post-monsoon above permissible limits for drinking, while rest of the parameters fall within the limits. Irrigation suitability was checked using sodium absorption ratio (SAR), residual sodium carbonate (RSC), percent sodium $(\mathrm{Na} \%)$ and permeability index (PI). Most of the samples fall under good to suitable category during premonsoon period, but fall under doubtful to unsuitable category during post-monsoon period. Presence of high salt content in groundwater during post-monsoon season reflects leaching of salts present in the unsaturated zone by infiltrating precipitation. Hydrochemical data was interpreted using Piper's trilinear plot and Chadha's plot to understand the various geochemical processes affecting the groundwater quality. The results indicate that the order of cation dominance is $\mathrm{Na}^{+}>\mathrm{Mg}^{2+}>\mathrm{Ca}^{2+}$, while anion
\end{abstract}

Tirumalesh Keesari

tirumal@barc.gov.in

1 Department of Environment Studies, Panjab University, Chandigarh 160014, India

2 Isotope Hydrology Section, Isotope Production and Applications Division, Bhabha Atomic Research Centre, Mumbai 400085, India dominance is in the order $\mathrm{Cl}^{-}>\mathrm{HCO}_{3}{ }^{-}>\mathrm{SO}_{4}{ }^{2-}$. The geochemistry of groundwater of this district is mainly controlled by the carbonate and silicate mineral dissolution and ion exchange during pre-monsoon and leaching from the salts deposited in vadose zone during post-monsoon. The main sources of contamination are soluble fertilizers and livestock wastes. This study is significant as the surface water resources are limited and the quality and quantity of groundwater are deteriorating with time due to anthropogenic inputs.

Keywords Geochemistry - Temporal variation .

Potability $\cdot$ SAR $\cdot$ Groundwater quality $\cdot$ Semi-arid .

Bathinda

\section{Introduction}

The sustainable socioeconomic development of every community depends on the availability of freshwater resources. Among different types of freshwater resources available, groundwater provides a significant fraction of the total supply for domestic, industrial and agricultural sectors of many countries. Water shortage has become an increasingly serious problem, especially in the arid and semi-arid regions of India, where the average annual precipitation is less than $500 \mathrm{~mm}$ (Keesari et al. 2014). The main factors that are responsible for the increased dependency on groundwater resources are, limited availability of surface water and failure of monsoonal rains. Unlike surface waters, groundwater is resistant to immediate quality deterioration as contaminants are either diluted or degraded during the course of water travel through vadose zone. Alluvial aquifers are typically characterized by fast variations in groundwater quality both in temporal and spatial 
scales. Hence, monitoring the alluvial aquifers, especially in urbanized zones, is important due to their susceptibility to anthropogenic contamination (Bhattacharya et al. 2008; Kumar et al. 2009; Ramanathan et al. 2009; Sidhu et al. 2013).

Punjab is an agriculture-dominant state and much of the irrigation needs are met by groundwater resources. Longterm precipitation data indicate that the decline in rainfall has been 40-50 \% during the last two decades (PHRED 2014). In addition to the decline in rainfall, the surface water resources are also fully utilized, which led to overexploitation of groundwater resources for agriculture. Groundwater quality in this state is impacted by water logging, effluents emerging from thermal industries, brick kilns and other small- and large-scale industrial activities. Studies on water quality of this region by Krishan et al. (2013), Chopra and Krishan (2014), and Singh et al. (2011) have reported that about $47 \%$ of the groundwater is unfit for drinking and agricultural purposes due to high salinity. The causes for salinity, high sulfate, magnesium, sodium and potassium were found to be dissolution of evaporite deposits and foetid limestone/dolomite present in the formations of this region (Kochhar et al. 2007). The possible reason for the high alkaline nature of groundwater was attributed to fly ash contribution from the thermal power plants (Mittal and Arora 2014). Health problems such as cancer, fluorosis and gastrointestinal irritation in residents of this district were also reported in many studies. A periodic monitoring of water quality is essential to understand the quality degradation and also to plan the remedial measures to control further damage. However, there are no detailed studies conducted in Bathinda district of Punjab in recent times. Therefore, a hydrochemical investigation was carried out in this district covering both shallow and deep zone groundwater to understand the changing scenario of the groundwater chemistry, to evaluate the effect of rainwater recharge and to identify the processes and factors impacting the groundwater quality.

\section{Study area description}

Bathinda district lies between $29^{\circ} 33^{\prime}$ and $30^{\circ} 36^{\prime} \mathrm{N}$ latitudes and $74^{\circ} 38^{\prime}$ and $75^{\circ} 46^{\prime} \mathrm{E}$ longitudes covering an area of $3367 \mathrm{~km}^{2}$. The study area is bounded by Sirsa and Fatehabad districts of Haryana state in the south, Sangrur district in the east, Moga in the northeast and Faridkot and Muktsar districts in the northwest. This region has a good network of canals to meet the demand of irrigation and domestic needs. The study area along with the canal network is given in Fig. 1. The study area is occupied by Indo-Gangetic alluvial plain belonging to Quaternary age (GSI 1976). The sediments typically consist of fine- to medium-grained sand.
Kankar and sand with admixture of clay constitute the aquifer system of this area (Singh et al. 2011). Groundwater exits under both unconfined and confined conditions in these alluvial aquifers. The thickness of top aquifer ranges from 40 to $56 \mathrm{~m}$ followed by a thick clay bed of thickness 15-35 m beneath granular zone, which extends up to a depth of $300 \mathrm{~m}$ (CGWB 2007). A schematic lithological section as fence diagram is shown in Fig. 2. This diagram is modified from CGWB (2007). The general slope of the water table is towards southwest from north, northeast, east and southeast. Based on the groundwater draft, this district falls under critical category, and based on the agro-climatic zonation, it falls under western plain zone characterized by semi-arid (dry to sub-moist) climate zone. The normal annual rainfall of the study area is $400-500 \mathrm{~mm}$, which is unevenly distributed. The southwest monsoon (June to September) contributes about $82 \%$ of annual rainfall. Rest of the rainfall is contributed by non-monsoon months of the year (CGWB 2013; Singh et al. 2011). The depth to water level lies between 2 and $5 \mathrm{~m}$ in most of the wells near the canal command area, while rest of the region shows depth to water level between 10 and $20 \mathrm{~m} \mathrm{bgl} \mathrm{(CGWB} \mathrm{2014).}$

\section{Sampling and measurement}

A total of 36 water samples were collected from canals, existing hand pumps, bore wells, tube wells tapping different depths and covering different parts of the district during both pre-monsoon (18 nos.) and post-monsoon (18 nos.) seasons. In general, hand pumps tap shallow depths (10-50 m bgl), while bore wells and tube wells tap both shallow and deep groundwater (15-150 mg bgl). Sample locations are shown in Fig. 1. Samples were collected from the four blocks in the district that are classified as safe for groundwater development potential (CGWB 2007). The blocks include Bathinda, Sangat, Talwandi Sabo and Maur. The samples were filtered using $0.45-\mu \mathrm{m}$-pore-size membrane filters and stored in polyethylene bottles that were initially washed with nitric acid and rinsed thoroughly with distilled water. Another set was collected and acidified to $\mathrm{pH}=2$ by adding ultrapure nitric acid for cation measurements. Physical parameters like $\mathrm{pH}$, conductivity and temperature were measured in situ using field kit, whereas chemical analysis was carried out in the laboratory. Alkalinity was measured by titrating $10 \mathrm{~mL}$ of water sample with $0.02 \mathrm{~N} \mathrm{H}_{2} \mathrm{SO}_{4}$ by Gran titration method. Major cations such as $\mathrm{Ca}^{2+}$ and $\mathrm{Mg}^{2+}$ were analyzed by titration method, $\mathrm{Na}^{+}$and $\mathrm{K}^{+}$by flame photometer 128 (Systronics), chloride by titration method and $\mathrm{NO}_{3}{ }^{-}, \mathrm{F}^{-}, \mathrm{SO}_{4}{ }^{2-}$ by spectrophotometer (Spectronic $21 \mathrm{D}$ ). All the analytical procedures were followed in compliance with standard protocols (APHA 1998). 

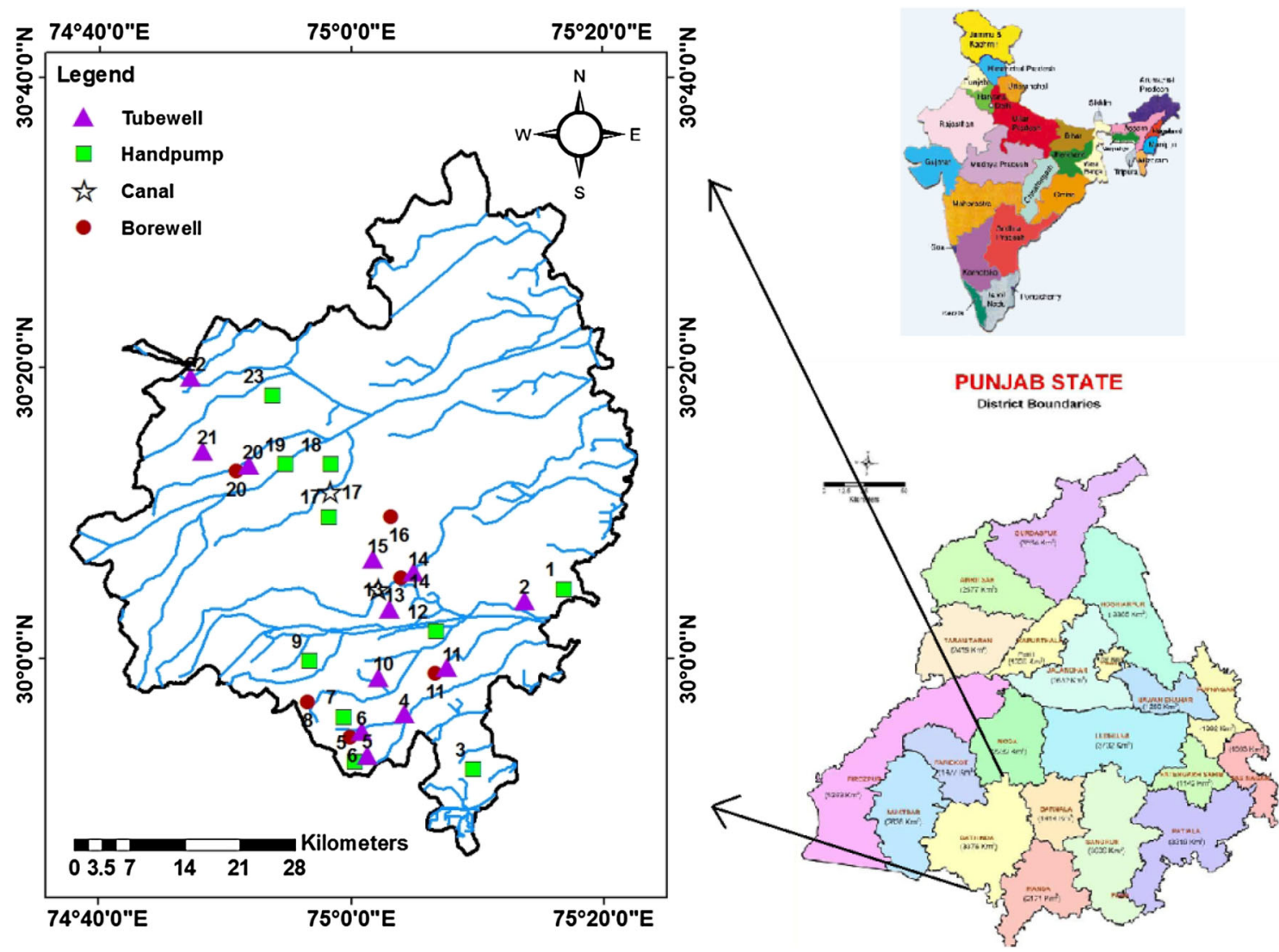

Fig. 1 Location of the Bathinda district and the sample locations

Fig. 2 Fence diagram of the study area depicting the distribution of pervious, impervious and semipervious strata (modified from CGWB 2007)

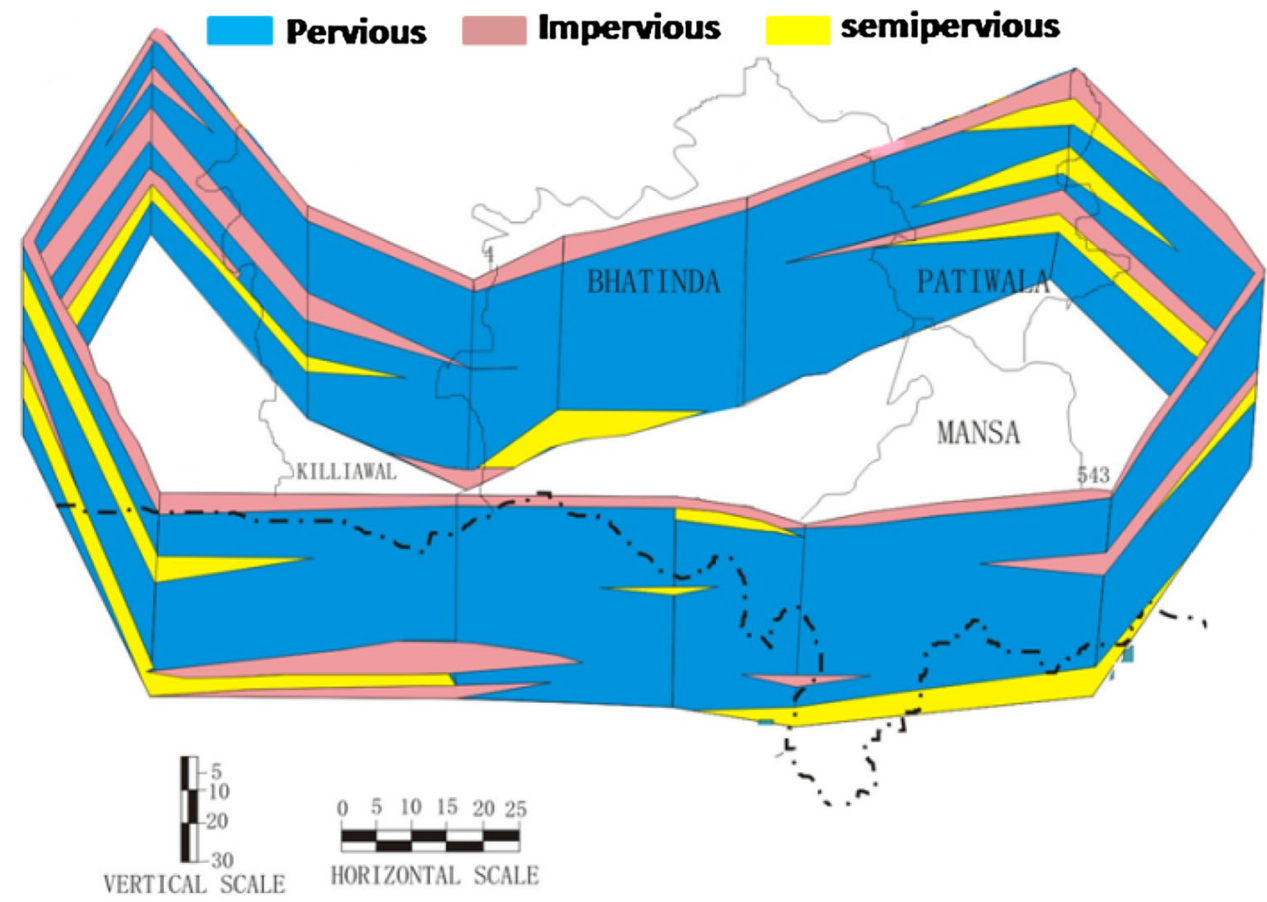

N

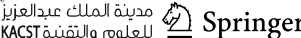


The accuracy of the chemical ion data was calculated using charge balance equation given below, and the charge balance error (CBE) of most of the samples was within the accepted limits of $\pm 5 \%$ (Hounslow 1995).

$\operatorname{CBE}(\%)=\frac{\operatorname{meq}(\text { cations })-\operatorname{meq}(\text { anions })}{\text { meq }(\text { cations })+\operatorname{meq}(\text { anions })} \times 100$

\section{Result and discussion}

\section{Physicochemical parameters}

The hydrochemical data of pre- and post-monsoon seasons are summarized in Table 1 . The temporal variation of the data is shown in box-whisker plots (Figs. 3a-i, 4a-i). Temperature was measured during one season (pre-monsoon) and it varied from 21.1 to $35.4{ }^{\circ} \mathrm{C}$ (Table 1). The $\mathrm{pH}$ values in this area ranged from 6.2 to 8.7 with an average value of 7.5 during pre-monsoon and 7.0-7.9 with an average value of 7.3 during post-monsoon (Table 1). It is commonly observed that groundwater that is uncontaminated shows $\mathrm{pH}$ value in the range of 6.0-9.0 and is influenced by carbon dioxide input from the atmosphere, microbial activity and plant photosynthesis (Hitchon et al. 1999). The
$\mathrm{pH}$ variations in the study area reflect that groundwater is not highly impacted by any of the microbial or other processes. Also, the mean values of $\mathrm{pH}$ suggest that groundwater does not show significant seasonal variation in $\mathrm{pH}$ (Figs. 3a, 4a). Most of the samples show $\mathrm{pH}$ values within drinking water permissible limits of 6.5-8.5 (Table 2).

Electrical conductivity (EC) represents the measure of the dissolved ions and salinity. High EC in water samples could be due to leaching or dissolution of the aquifer material or mixing of saline sources or a combination of these processes (Hem 1991; Hounslow 1995). The groundwater samples of this district showed EC in the range of $174-4014 \mu \mathrm{S} / \mathrm{cm}$ with an average value of 1336 $\mu \mathrm{S} / \mathrm{cm}$ during pre-monsoon and 269-3806 $\mu \mathrm{S} / \mathrm{cm}$ with an average value of $1956 \mu \mathrm{S} / \mathrm{cm}$ during post-monsoon (Table 1). The TDS of the samples collected during premonsoon varied from 122 to $2811 \mathrm{mg} / \mathrm{L}$ with an average value of $935 \mathrm{mg} / \mathrm{L}$, while during post-monsoon, it varied from 188 to $2657 \mathrm{mg} / \mathrm{L}$ with an average value of $1366 \mathrm{mg} /$ $\mathrm{L}$ (Table 1). The increase in TDS after monsoon can be attributed to contribution of salts from unsaturated zone, which dissolve in the infiltrating water that ultimately reach the water table. The variability in the TDS is similar in both the seasons (Figs. 3b, 4b).

Table 1 Statistics of groundwater chemistry of both seasons

\begin{tabular}{|c|c|c|c|c|c|c|c|c|c|}
\hline \multirow[t]{3}{*}{ S. no. } & \multirow[t]{3}{*}{ Parameter } & \multicolumn{4}{|c|}{ Pre-monsoon } & \multicolumn{4}{|c|}{ Post-monsoon } \\
\hline & & \multicolumn{2}{|l|}{ Range } & \multirow[t]{2}{*}{ Mean } & \multirow[t]{2}{*}{ Std. dev. } & \multicolumn{2}{|c|}{ Range } & \multirow[t]{2}{*}{ Mean } & \multirow[t]{2}{*}{ Std. dev } \\
\hline & & Min. & Max. & & & Min. & Max. & & \\
\hline 1. & $\mathrm{pH}$ & 6.19 & 8.69 & 7.49 & 0.52 & 7 & 7.95 & 7.33 & 0.27 \\
\hline 2 & Temp. $\left({ }^{\circ} \mathrm{C}\right)$ & 21.1 & 35.38 & 27.85 & 2.8 & - & - & - & - \\
\hline 3. & $\mathrm{EC}(\mu \mathrm{S} / \mathrm{cm})$ & 174 & 4014 & 1336 & 1083 & 269 & 3806 & 1956 & 1191 \\
\hline 4. & TDS (mg/L) & 122 & 2811 & 935 & 758 & 188 & 2657 & 1366 & 831 \\
\hline 5. & TH (mg/L) & 104.8 & 1467 & 391 & 334.3 & 161 & 1280.3 & 525 & 282.3 \\
\hline 6. & $\mathrm{Ca}^{2+}(\mathrm{mg} / \mathrm{L})$ & 1.7 & 67.3 & 29.3 & 21.1 & 22 & 147 & 60 & 34.2 \\
\hline 7. & $\mathrm{Mg}^{2+}(\mathrm{mg} / \mathrm{L})$ & 0.98 & 351 & 77.2 & 88 & 15.1 & 226 & 91.2 & 59.4 \\
\hline 8. & $\mathrm{Na}^{+}(\mathrm{mg} / \mathrm{L})$ & 3.6 & 570 & 155 & 188 & 5.4 & 680 & 238 & 227 \\
\hline 9. & $\mathrm{~K}^{+}(\mathrm{mg} / \mathrm{L})$ & 1.6 & 20.6 & 5.76 & 4.5 & 1.2 & 13 & 6.47 & 2.9 \\
\hline 10. & $\mathrm{Cl}^{-}(\mathrm{mg} / \mathrm{L})$ & 14.2 & 1278 & 288 & 323 & 42.6 & 788 & 293 & 227 \\
\hline 11. & $\mathrm{HCO}_{3}{ }^{-}(\mathrm{mg} / \mathrm{L})$ & 115 & 815 & 413 & 214 & 150 & 780 & 423 & 148 \\
\hline 12. & $\mathrm{NO}_{3}^{-}(\mathrm{mg} / \mathrm{L})$ & 1.08 & 69.6 & 6.8 & 16 & 0 & 390 & 47.6 & 89 \\
\hline 13. & $\mathrm{SO}_{4}{ }^{2-}(\mathrm{mg} / \mathrm{L})$ & 84 & 506 & 272 & 154 & 4.5 & 518 & 273 & 164 \\
\hline 14. & $\mathrm{~F}^{-}(\mathrm{mg} / \mathrm{L})$ & 1.3 & 1.9 & 1.6 & 0.2 & 0 & 3 & 1.3 & 0.9 \\
\hline
\end{tabular}

Sample point in map 1-DB1; 2-B1,DB2; 3-DB3; 4-B9,BD4; 5-B8,DB5; 6-B7,DB6; 7-B6; 8-DB7; 9-B5; 10-B10,DB8; 11-B16,DB13; 12-B17,B18; 13-DB10,DB11; 14-B2,B3; 15-DB12; 16-DB13; 17-DB14,DB15; 18-B11,DB16; 19-B12; 20-B13,DB17; 21-B14; 22-B15; 23-DB18

$E C$ electrical conductivity, $T D S$ total dissolved salts, $T H$ total hardness, all the values are in $\mathrm{mg} / \mathrm{L}$ except $\mathrm{pH}, \mathrm{EC}(\mu \mathrm{S} / \mathrm{cm})$ and temperature $\left({ }^{\circ} \mathrm{C}\right)$. Min. minimum, Max. maximum, Std. Dev. standard deviation 
Fig. 3 Box-whisker plot of the groundwater samples of premonsoon season, Bathinda, a $\mathrm{pH}, \mathbf{b} \mathrm{TDS}, \mathbf{c} \mathrm{Ca}^{2+}, \mathbf{d ~} \mathrm{Mg}^{2+}$, e $\mathrm{Na}^{+}, \mathbf{f ~ K}{ }^{+}, \mathbf{g ~ C l}{ }^{-}, \mathbf{h ~} \mathrm{HCO}_{3}{ }^{-}$, and $\mathbf{i} \mathrm{SO}_{4}{ }^{2-}$. All parameters are in $\mathrm{mg} / \mathrm{L}$ except $\mathrm{pH}$
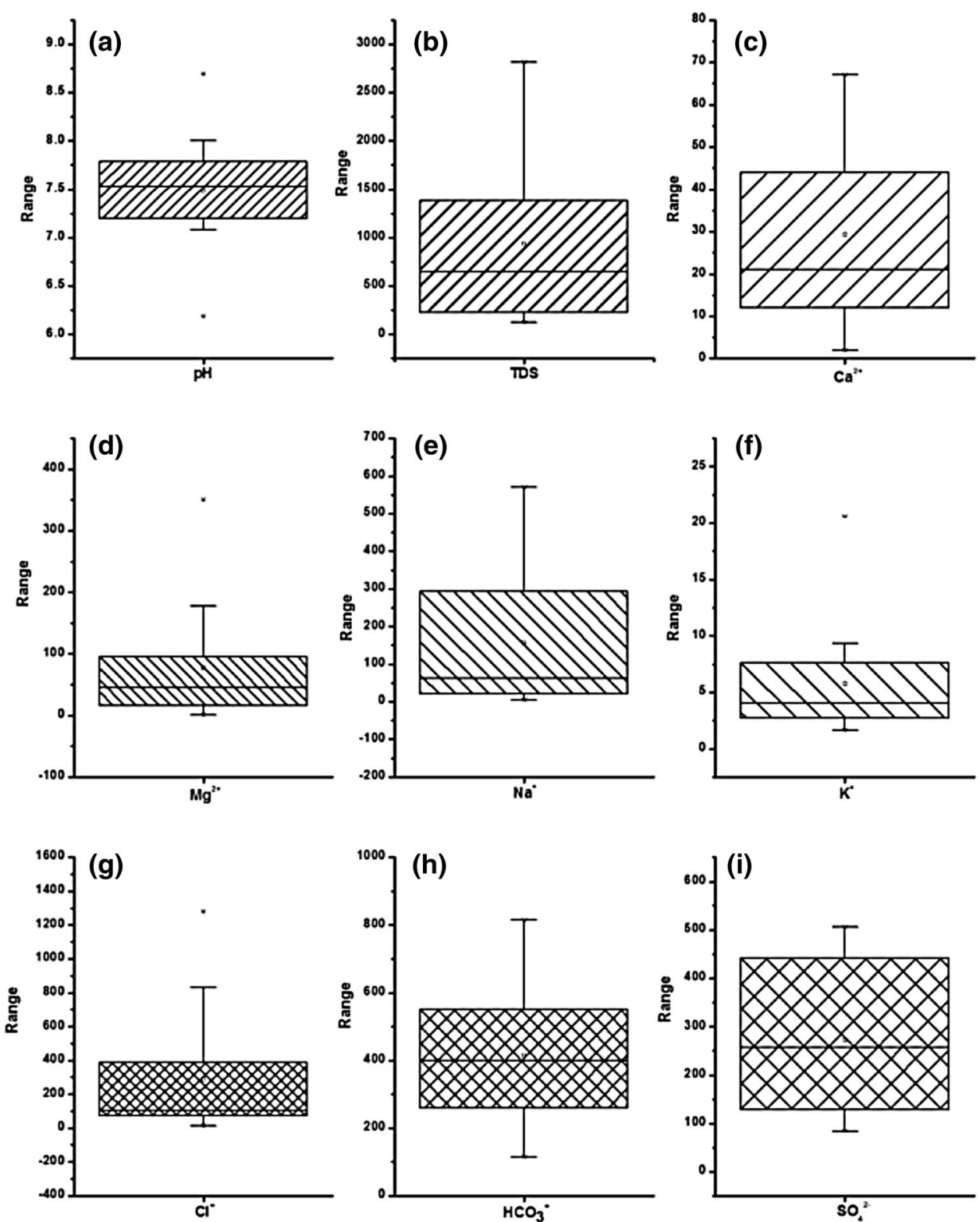

\section{Suitability for drinking purposes}

The analytical results have been examined for suitability for domestic purposes based on WHO (2011) and BIS (2012). The values of different water quality parameters and percentage samples falling beyond the permissible limits as per WHO and BIS are given in Table 2. From the table, it can be observed that groundwater is mostly contaminated by $\mathrm{F}^{-}$in $72 \%$ of the samples followed by $25 \%$ $\mathrm{TH}$ and $22 \% \mathrm{Mg}^{2+}$ in the pre-monsoon, while in the postmonsoon, the order is $50 \% \mathrm{~F}^{-}, 39 \% \mathrm{Mg}^{2+}$ and $28 \% \mathrm{TH}$. Major ions concentrations along with TH, TDS and EC values are found to be higher in the post-monsoon season compared to pre-monsoon (Figs. 3, 4).
Usability of water for drinking, irrigation and industrial purposes is generally assessed by TDS and TH (BIS 2012; WHO 2011). TDS refers to the total dissolved solids present in the water and is estimated empirically from electrical conductivity values. In the present study, TDS was calculated as follows:

$\operatorname{TDS}(\mathrm{mg} / \mathrm{L})=0.67 \times$ Conductivity $(\mu \mathrm{S} / \mathrm{cm})$

Higher concentration of TDS causes gastrointestinal irritation in human and may also lead to laxative effects. TDS in groundwater of this region ranged from 122 to $2811 \mathrm{mg} / \mathrm{L}$ with a mean value of $935 \mathrm{mg} / \mathrm{L}$ during premonsoon and $188-2657 \mathrm{mg} / \mathrm{L}$ with a mean value of $1366 \mathrm{mg} / \mathrm{L}$ during post-monsoon. The main factor for the 
Fig. 4 Box-whisker plot of the groundwater samples of postmonsoon season, Bathinda. a $\mathrm{pH}, \mathbf{b} \mathrm{TDS}, \mathbf{c} \mathrm{Ca}^{2+}, \mathbf{d ~} \mathrm{Mg}^{2+}$, e $\left.\mathrm{Na}^{+}, \mathbf{f ~ K}{ }^{+}, \mathbf{g ~ C l}{ }^{-}, \mathbf{h}\right) \mathrm{HCO}_{3}{ }^{-}$, and $\mathrm{i} \mathrm{SO}_{4}{ }^{2-}$. All parameters are in $\mathrm{mg} / \mathrm{L}$ except $\mathrm{pH}$
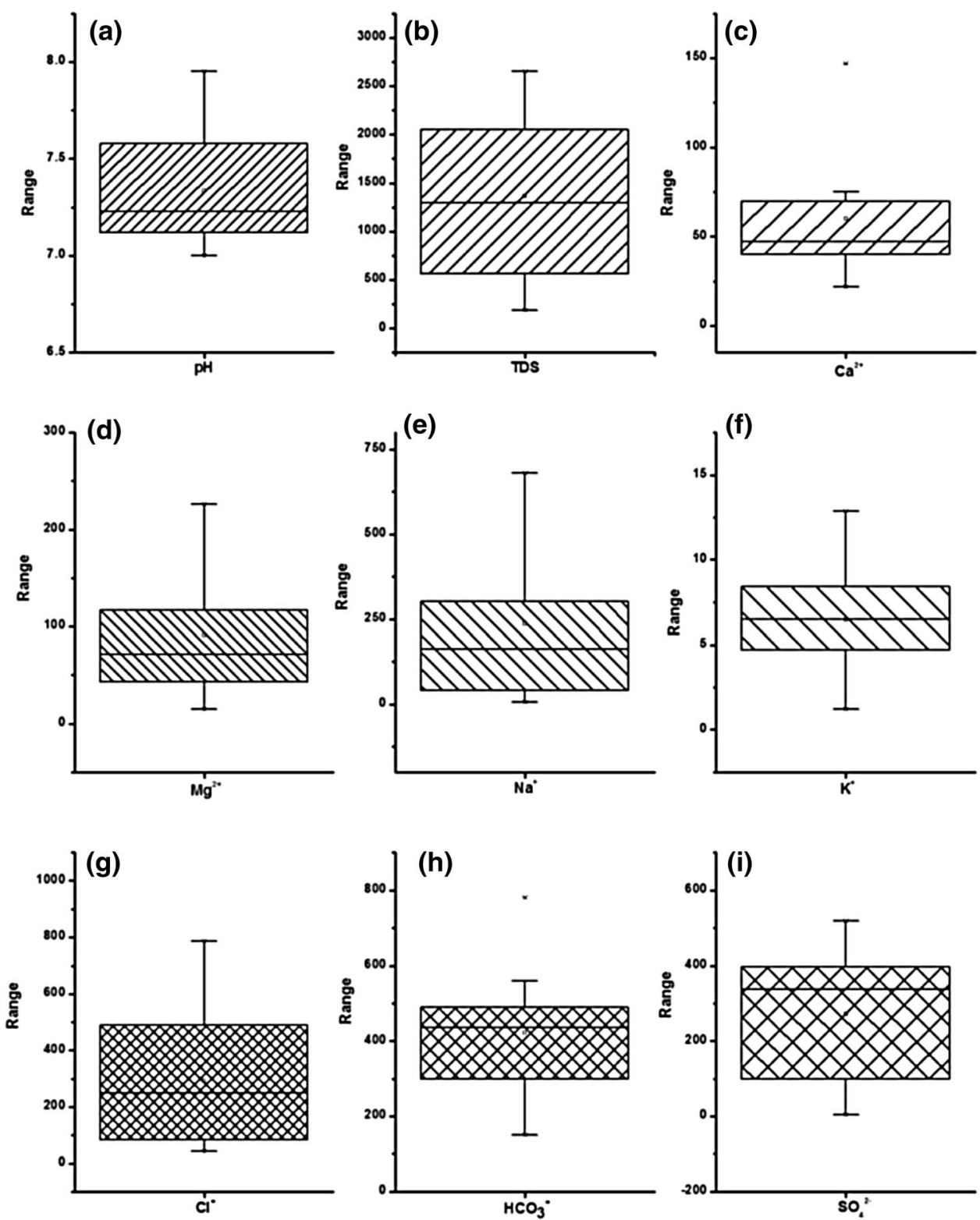

enrichment of TDS is dissolution of salts and evaporation of water. Classification of groundwater based on TDS values (Davies and DeWiest 1966) is presented in Table 3. As per this classification, $22.2 \%$ samples for both seasons were found to be permissible for drinking. Higher percentage of the samples in pre-monsoon falls in the desirable for drinking category compared to post-monsoon season. This clearly indicates that contribution of salts from the unsaturated zone to the shallow aquifers by infiltrating rainwater increases the TDS of groundwater during postmonsoon season. However, post-monsoon samples can be classified as "irrigation suitable".

Total hardness $(\mathrm{TH})$ is caused by various dissolved salts of $\mathrm{Ca}^{2+}$ and $\mathrm{Mg}^{2+}$ and is often a critical parameter used for assessing drinking water suitability. Consumption of water with high TH may raise the risk of calcification of arteries, urinary concretions, diseases of kidney or bladder or stomach disorder.

TH was determined by the following equation (Todd 1980) and expressed as mg/L of $\mathrm{CaCO}_{3}$ :

$\mathrm{TH}=2.497 \times \mathrm{Ca}^{2+}+4.115 \times \mathrm{Mg}^{2+}$

where $\mathrm{Mg}^{2+}, \mathrm{Ca}^{2+}$ and $\mathrm{TH}$ concentrations are expressed in $\mathrm{mg} / \mathrm{L}$. The TH levels in groundwater of this district are in the range of $105-1467 \mathrm{mg} / \mathrm{L}$ during pre-monsoon and 161-1280 mg/L during post-monsoon. Water classification based on TH (Durfor and Becker 1964) is given in Table 3. Majority of the samples fall in very hard category for both 


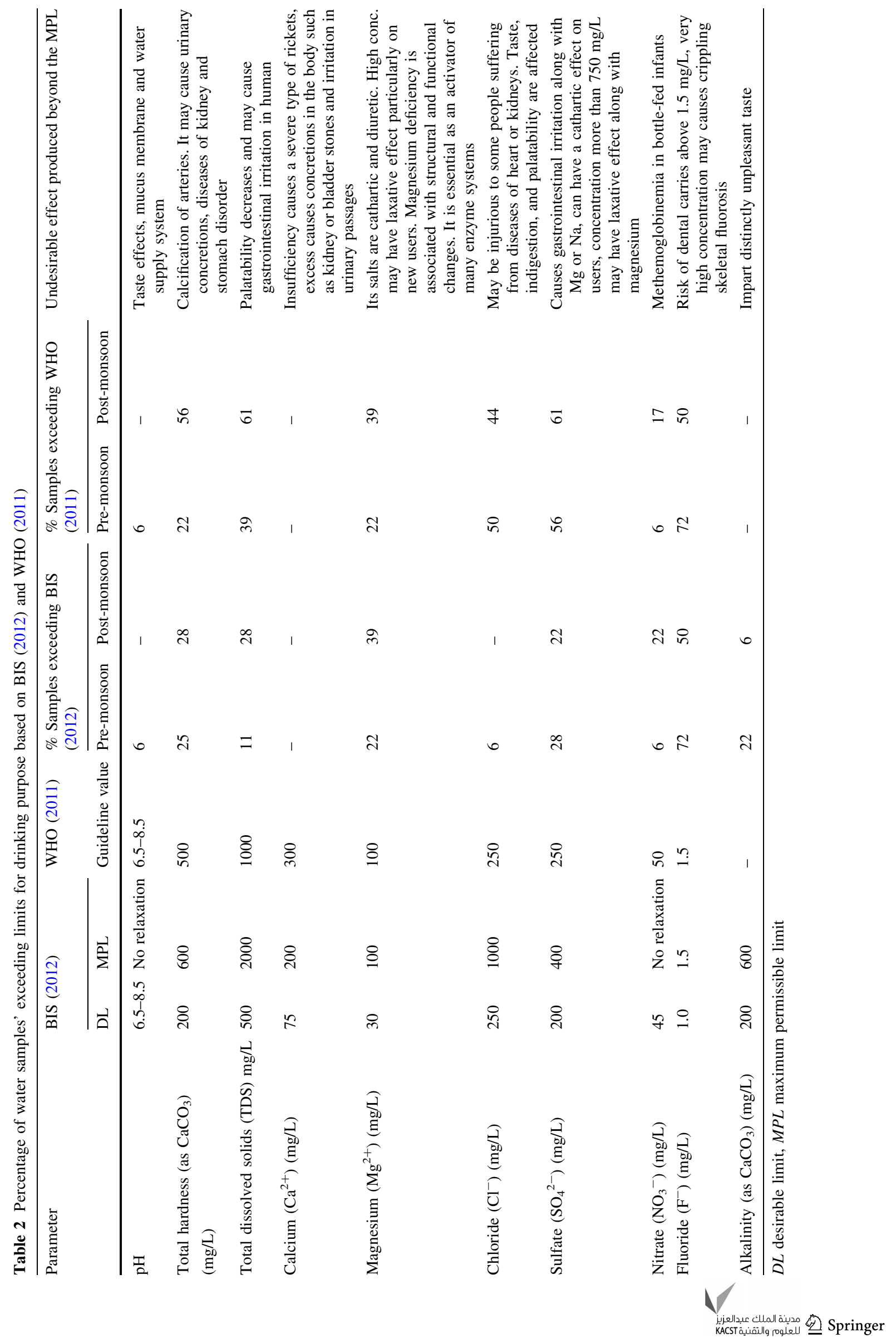


Table 3 Suitability of groundwater for drinking based on TDS and TH

\begin{tabular}{llll}
\hline & Water class & $\begin{array}{l}\text { \% of samples } \\
\text { in pre-monsoon }\end{array}$ & $\begin{array}{l}\text { \% of samples in } \\
\text { post-monsoon }\end{array}$ \\
\hline $\begin{array}{l}\text { TDS }(\mathrm{mg} / \mathrm{L}) \\
<500\end{array}$ & $\begin{array}{l}\text { Desirable for drinking } \\
500-1000\end{array}$ & 38.9 & 16.7 \\
$1000-3000$ & Permissible for drinking & 22.2 & 22.2 \\
$>3000$ & Useful for irrigation & 38.9 & 61.1 \\
$\mathrm{TH}\left(\mathrm{mg} \mathrm{CaCO}_{3} / \mathrm{L}\right)$ & Unfit for drinking and irrigation & - & - \\
$<60$ & & & - \\
$60-120$ & Soft & - & - \\
$121-181$ & Moderately hard & 11.1 & 11.1 \\
$>180$ & Hard & 16.7 & 88.9 \\
\hline
\end{tabular}

the seasons (Table 3). Total hardness of more than $180 \mathrm{mg}$ $\mathrm{CaCO}_{3} / \mathrm{L}$ can be treated as very hard water and can lead to scaling problems in air-conditioning plants (Hem 1991).

Sodium $\left(\mathrm{Na}^{+}\right)$concentration in the study area ranged from 3.6 to $570 \mathrm{mg} / \mathrm{L}$ with a mean value of $155 \mathrm{mg} / \mathrm{L}$ in the pre-monsoon period, while it ranged from 5.4 to $680 \mathrm{mg} / \mathrm{L}$ in the post-monsoon period with a mean value of $238 \mathrm{mg} / \mathrm{L}$ (Table 1). The common sources of $\mathrm{Na}^{+}$in this region are weathering of minerals like feldspar and application of fertilizers. Among other major cations, calcium $\left(\mathrm{Ca}^{2+}\right)$ and magnesium $\left(\mathrm{Mg}^{2+}\right)$ ions are important constituents, which control the water hardness. Calcium is present in groundwater due to its easy solubility and abundance in most rock. In drinking water, the desirable limit of calcium is $75 \mathrm{mg} / \mathrm{L}$ and permissible limit in the absence of alternative source of water is $200 \mathrm{mg} / \mathrm{L}$ as per BIS (2012) and $300 \mathrm{mg} / \mathrm{L}$ as per WHO (2011). $\mathrm{Ca}^{2+}$ ranged from 1.7 to $67.3 \mathrm{mg} / \mathrm{L}$ with a mean value of $29.3 \mathrm{mg} / \mathrm{L}$ in the pre-monsoon period, while in the post-monsoon period, it ranged from 21.9 to $147 \mathrm{mg} /$ $\mathrm{L}$ with an average value of $60 \mathrm{mg} / \mathrm{L}$ (Table 1). $\mathrm{Mg}^{2+}$ concentration in the study area ranged from 0.98 to $351 \mathrm{mg} / \mathrm{L}$ with a mean value of $77.2 \mathrm{mg} / \mathrm{L}$ in the premonsoon period, while it ranged from 15.1 to $226 \mathrm{mg} / \mathrm{L}$ in the post-monsoon period with a mean value of $91.2 \mathrm{mg} / \mathrm{L}$ (Table 1). Magnesium is essential as an activator of many enzyme systems, but it is also cathartic and diuretic. Both $\mathrm{Ca}^{2+}$ and $\mathrm{Mg}^{2+}$ are derived from the silicate rocks as well as dolomitic deposits. Potassium $\left(\mathrm{K}^{+}\right)$occurs in drinking water as a consequence of the use of potassium permanganate as an oxidant in water treatment (WHO 2011). It ranged from 1.6 to $20.6 \mathrm{mg} / \mathrm{L}$ with a mean value of $5.76 \mathrm{mg} / \mathrm{L}$ in the pre-monsoon period, while in the postmonsoon period, it ranged from 1.2 to $12.9 \mathrm{mg} / \mathrm{L}$ with an average value of $6.47 \mathrm{mg} / \mathrm{L}$ (Table 1). Potassium might be derived from anthropogenic sources like potash feldspar. $\mathrm{K}^{+}$is an essential element for both plants and animals, however, high concentration may be harmful to human nervous and digestive systems due to its laxative effects.
Bicarbonate $\left(\mathrm{HCO}_{3}{ }^{-}\right)$in groundwater of this region ranged from 115 to $815 \mathrm{mg} / \mathrm{L}$ with a mean value of $413 \mathrm{mg} /$ $\mathrm{L}$ during pre-monsoon period, while it ranged from 150 to $780 \mathrm{mg} / \mathrm{L}$ with a mean value of $423 \mathrm{mg} / \mathrm{L}$ during postmonsoon period (Table 1). $\mathrm{Cl}^{-}$in groundwater ranged from 14.2 to $1278 \mathrm{mg} / \mathrm{L}$ with a mean value of $288 \mathrm{mg} / \mathrm{L}$ during pre-monsoon period, while it ranged from 42.6 to $788 \mathrm{mg} / \mathrm{L}$ with a mean value of $293 \mathrm{mg} / \mathrm{L}$ during post-monsoon (Table 1). Chloride in drinking water is not generally harmful to human unless present in higher concentration. High concentration of $\mathrm{Cl}^{-}$renders salty taste to water and beverages. Consumption of high-chloride water leads to health issues related to hypertension, ventricular hypertrophy, osteoporosis, renal stones and asthma (McCarthy 2004). $\mathrm{SO}_{4}{ }^{2-}$ in groundwater of pre-monsoon season ranged from 84 to $506 \mathrm{mg} / \mathrm{L}$ with a mean value of $272 \mathrm{mg} / \mathrm{L}$, while it ranged from 4.5 to $518 \mathrm{mg} / \mathrm{L}$ with a mean value of $273 \mathrm{mg} / \mathrm{L}$ in the post-monsoon period (Table 1).

Nitrate $\left(\mathrm{NO}_{3}{ }^{-}\right)$and fluoride $\left(\mathrm{F}^{-}\right)$are widespread inorganic contaminants in groundwater in India endangering the groundwater resources many states. The $\mathrm{NO}_{3}{ }^{-}$concentration in groundwater of this area ranged from 1 to $70 \mathrm{mg} / \mathrm{L}$ during pre-monsoon with mean value of 6.8 and 0-390 $\mathrm{mg} / \mathrm{L}$ with a mean value of $47.6 \mathrm{mg} / \mathrm{L}$ during postmonsoon (Table 1). $22 \%$ samples in post-monsoon showed very high values above the permissible limit (Table 2). $\mathrm{NO}_{3}{ }^{-}$being soluble and mobile, is prone to leaching through soils along with infiltrating water, and high $\mathrm{NO}_{3}{ }^{-}$levels in potable water lead to methemoglobinemia (blue baby syndrome) in infants. The common sources of $\mathrm{NO}_{3}{ }^{-}$in this region are decaying organic matter, domestic wastes (David and Gentry 2000) and fertilizers (Tripathi et al. 2000). $\mathrm{F}^{-}$concentration in the study area varied $\mathrm{L}$ with/L with a mean value of $1.6 \mathrm{mg} / \mathrm{L}$ in the pre-monsoon, while it ranged from 0 to $3 \mathrm{mg} / \mathrm{L}$ with mean value of $1.3 \mathrm{mg} / \mathrm{L}$ in the post-monsoon (Table 1 ). All the samples contain $\mathrm{F}^{-}$levels equal to or greater than the drinking water permissible limit of $1.5 \mathrm{mg} / \mathrm{L}$ (Table 2). 
High fluoride may be due to leaching from fluoride-rich rocks present in the subsurface as well as due to anthropogenic activities. Similar reports on contribution of industrial effluents for high $\mathrm{F}^{-}$in groundwater is reported in India (Chatterjee et al. 2008; Keesari et al. 2007). Consumption of groundwater with high $\mathrm{F}^{-}$results in mottling of teeth or dental fluorosis followed by skeletal fluorosis (Ray et al. 1981).

\section{Suitability for irrigation}

The suitability of groundwater for irrigation is mainly evaluated using electrical conductivity (EC), sodium adsorption ratio (SAR), residual sodium carbonate (RSC), percent of sodium $(\mathrm{Na} \%)$ and permeability index (PI). USSL diagram (SAR versus EC plot) and Wilcox diagram (Na\% versus EC plot) were also applied to evaluate the irrigation suitability of groundwater in many instances. The suitability of groundwater for irrigation based on EC is classified into four groups (Richards 1954) and the percentages are given in Table 4. It was found that about $22 \%$ of the samples fall in either doubtful or unsuitable category during pre-monsoon, and it raises to $44 \%$ in post-monsoon (Table 4). High concentration of $\mathrm{Na}^{+}$in irrigation water affects the soil permeability and the texture. This makes the soil hard to plough and unsuitable for seedling emergence

Table 4 Suitability of groundwater for irrigation

\begin{tabular}{llll}
\hline & Water class & $\begin{array}{l}\text { \% of samples in } \\
\text { pre-monsoon }\end{array}$ & $\begin{array}{l}\% \text { of samples in } \\
\text { post-monsoon }\end{array}$ \\
\hline EC $(\mu \mathrm{S} / \mathrm{cm})$ & & & \\
$<250$ & Excellent & 5.6 & 0.0 \\
$250-750$ & Good & 33.3 & 16.7 \\
$750-2000$ & Permissible & 38.9 & 44.4 \\
$2000-3000$ & Doubtful & 16.7 & 16.7 \\
$>3000$ & Unsuitable & 5.6 & 22.2 \\
Alkalinity hazard (SAR) & & \\
$<10$ & Excellent & 89 & 89 \\
$10-18$ & Good & 11 & 11 \\
$18-26$ & Doubtful & - & - \\
$>26$ & Unsuitable & - & - \\
Percent sodium & & & 27.78 \\
$<20$ & Excellent & 27.78 & 27.78 \\
$20-40$ & Good & 33.33 & 22.22 \\
$40-60$ & Permissible & 11.11 & 22.22 \\
$60-80$ & Doubtful & 22.22 & 0.00 \\
$>80$ & Unsafe & 5.56 & 89 \\
Residual sodium carbonate & & 11 \\
$<1.25$ & Good & 77.8 & 0 \\
$1.25-2.5$ & Doubtful & 0 & \\
$>2.5$ & Unsuitable & 22.2 & \\
\hline
\end{tabular}

(Trivedy and Goel 1984). This effect is monitored by sodium/alkali hazard, which is expressed as the SAR. This ratio is computed from the relative proportion of $\mathrm{Na}^{+}$ concentration to $\mathrm{Ca}^{2+}$ and $\mathrm{Mg}^{2+}$ concentrations in a given water sample. When the concentration of $\mathrm{Na}^{+}$ions is high in irrigation water, $\mathrm{Na}^{+}$replaces $\mathrm{Ca}^{2+}$ and $\mathrm{Mg}^{2+}$ ions absorbed onto the clay material. This exchange mechanism reduces the permeability of soil matter and eventually results in soil with poor internal drainage (Karanth 1987). The SAR values for each water sample were calculated using the following equation (Richards 1954):

$\mathrm{SAR}=\frac{\mathrm{Na}^{+}}{\sqrt{\frac{\mathrm{Ca}^{2+}+\mathrm{Mg}^{2+}}{2}}}$

where the concentrations are reported in equivalents per million. SAR values varied from 0.1 to 13 , and majority of the samples $(89 \%)$ fall in low alkali hazard class in premonsoon (Table 4). The SAR values during post-monsoon season also varied in a similar range (0.17-11), and majority of the samples fall in low alkali hazard class.

Sodium combines with inorganic carbon $\left(\mathrm{HCO}_{3}{ }^{-}\right.$and $\mathrm{CO}_{3}{ }^{2-}$ ) to form alkaline soils and combines with $\mathrm{Cl}^{-}$to form saline soils. Both these soils are not favorable for plant growth. This effect is commonly indicated by $\mathrm{Na} \%$ (Wilcox 1948) and expressed in epm (milliequivalents per liter). It is calculated using following equation:

$\mathrm{Na} \%=\frac{\left(\mathrm{Na}^{+}+\mathrm{K}^{+}\right) \times 100}{\mathrm{Ca}^{2+}+\mathrm{Mg}^{2+}+\mathrm{Na}^{+}+\mathrm{K}^{+}}$

A $\mathrm{Na} \%$ value of up to 60 in groundwater is considered as acceptable for agricultural purposes (Ramakrishna 1998). $\mathrm{Na} \%$ in groundwater of this study area showed a wide range of variation from 3 to $86 \%$ during premonsoon and 7-72\% during post-monsoon (Table 4). It was found that most of the samples fall in excellent to permissible class, and only about $22 \%$ were found to fall under doubtful to unsafe categories (Table 4). A similar trend was observed in the post-monsoon season as well. High $\mathrm{Na} \%$ in water coupled with high EC decreases the osmotic activity of plants and, thus, limits the absorption of water and nutrients from the soil. Wilcox diagram is commonly used to understand the combined effect of EC and $\mathrm{Na} \%$ (Wilcox 1955).

During pre-monsoon, $55.5 \%$ of the groundwater samples fall in excellent to good and good to permissible categories, while $44.5 \%$ samples fall in permissible to doubtful and doubtful to unsuitable categories (Fig. 5). In the case of post-monsoon season, $50 \%$ of the samples fall in doubtful to unsuitable and unsuitable categories. This clearly indicates that groundwater quality is better for irrigation during pre-monsoon than post-monsoon season. The poor groundwater quality during post-monsoon can be 


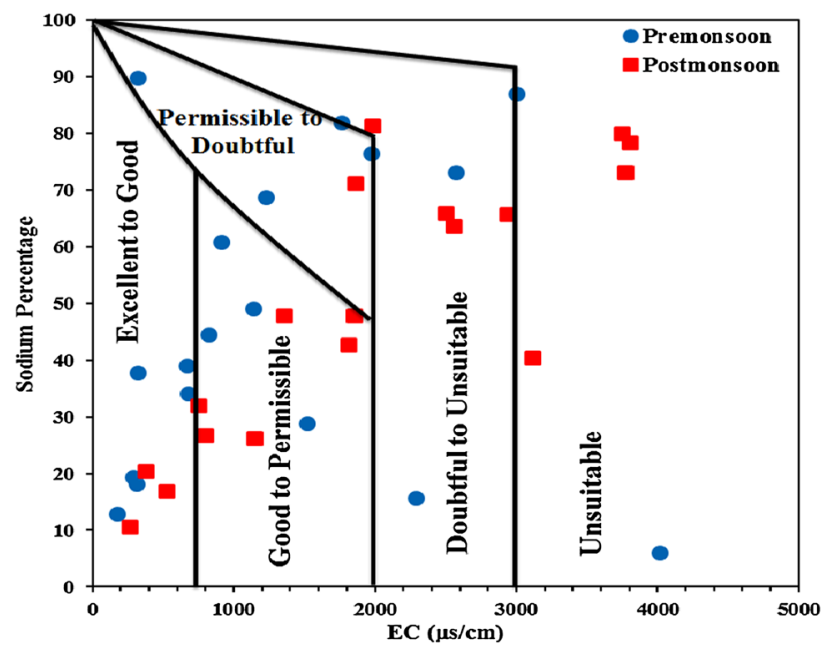

Fig. 5 Wilcox diagram of groundwater samples of Bathinda district

explained by the presence of high salt content containing mainly $\mathrm{Na}^{+}, \mathrm{HCO}_{3}{ }^{-}, \mathrm{SO}_{4}{ }^{2-}$ and $\mathrm{Cl}^{-}$ions.

United States Salinity Laboratory diagram depicts a detailed analysis of groundwater with respect to irrigational suitability (USSL 1954). As per this classification, lowsalinity water $(<250 \mu \mathrm{S} / \mathrm{cm})$ can be used in all types of soils (Fig. 6). Based on USSL classification the groundwater of the study area can be grouped into four zones, $\mathrm{C} 1 \mathrm{~S} 1, \mathrm{C} 2 \mathrm{~S} 1, \mathrm{C} 3 \mathrm{~S} 1$ and $\mathrm{C} 3 \mathrm{~S} 2$. Overall, $80 \%$ of the samples indicated medium to high salinity and low alkalinity water, which can be used for irrigation in almost all types of soils with little danger of exchangeable sodium.

In addition to SAR and $\mathrm{Na} \%$, the excess $\mathrm{CO}_{3}{ }^{2-}$ and $\mathrm{HCO}_{3}{ }^{-}$in groundwater over the sum of $\mathrm{Ca}^{2+}$ and $\mathrm{Mg}^{2+}$ ions also influences the suitability of groundwater for irrigation. This is defined as residual sodium carbonate (RSC). The water samples containing excess of $\mathrm{CO}_{3}{ }^{2-}$ and $\mathrm{HCO}_{3}{ }^{-}$ precipitate $\mathrm{CaCO}_{3}$ in soil from solution and increase $\mathrm{Na}^{+}$ concentration in water. This results in soil dispersion and limits nutrient uptake by plants. This also reduces water infiltration into the soil surface and further down the soil profile, thus limiting aeration and leading to reduced crop growth. RSC is calculated by the following equation:

$\mathrm{RSC}=\left(\mathrm{HCO}_{3}^{-}+\mathrm{CO}_{3}^{2-}\right)-\left(\mathrm{Ca}^{2+}+\mathrm{Mg}^{2+}\right)$

Water with RSC less than 1.25 is suitable for irrigation, whereas marginally suitable up to 2.5 and not suitable for irrigation above 2.5 (Lloyd and Heathcote 1985). In the study area, the RSC values ranged from -21 to 8.5 during pre-monsoon and -18.8 to 2.0 during post-monsoon. Majority of the samples falls under good category, $77.8 \%$ in pre-monsoon and $94 \%$ in post-monsoon (Table 4).

Permeability index (PI) influences quality of irrigation water in relation to soil development in agriculture. The soil permeability is affected by long-term use of irrigation

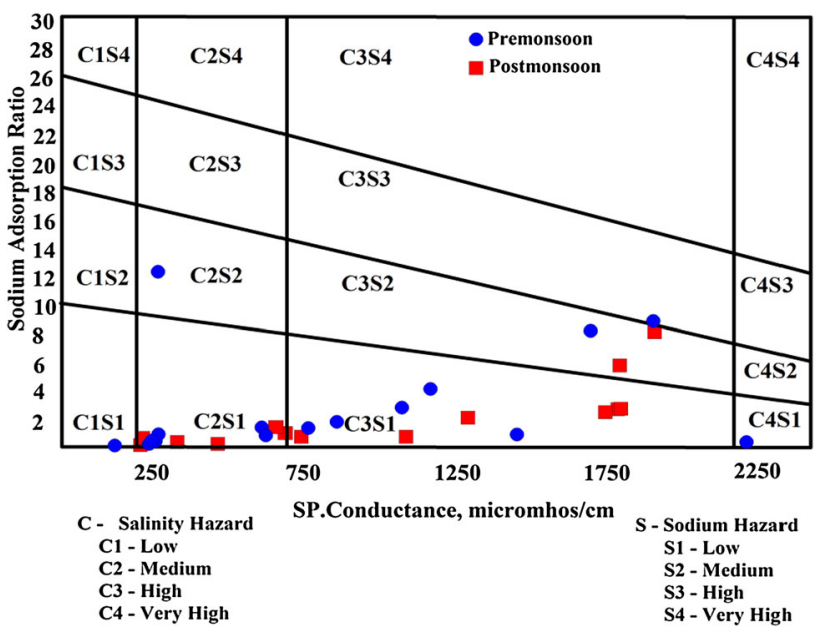

Fig. 6 USSL diagram of groundwater samples of Bathinda district

water and is influenced by $\mathrm{Na}^{+}, \mathrm{Ca}^{2+}, \mathrm{Mg}^{2+}$ and $\mathrm{HCO}_{3}{ }^{-}$ contents of the soil. PI is defined by:

$\mathrm{PI}=\frac{\mathrm{Na}^{+}+\sqrt{\mathrm{HCO}_{3}}}{\mathrm{Ca}^{2+}+\mathrm{Mg}^{2+}+\mathrm{Na}^{+}} \times 100$

where concentrations are in $\mathrm{meq} / \mathrm{L}$.

Doneen (1964) classified water into three classes based on PI. Groundwater falling in Class I is considered as $100 \%$ maximum permeable and is suitable for irrigation. Class II water shows $75 \%$ maximum permeability and is marginally suitable for irrigation. Class III water is associated with $25 \%$ maximum permeability and is unsuitable for irrigation. The PI values of groundwaters ranged from 12.3 to $107 \mathrm{meq} / \mathrm{L}$ during the pre-monsoon with an average value of about 63.4 , while it ranged from 35.6 to $86.7 \mathrm{meq} / \mathrm{L}$ with an average value of 58.2 during postmonsoon. The majority of the samples are in Class I followed by Class II, indicating that the water is moderate to good for irrigation purposes with a few samples showing poor irrigation quality. Figure 7 depicts the variation of the PI in pre- and post-monsoon samples. From the figure, it can be seen that both pre- and post-monsoon samples showed similar variations in PI and they mostly fall in the Class I category.

\section{Geochemical evolution of groundwater}

Major ion chemical data have been plotted on Piper trilinear diagram (Piper 1944) (Fig. 8) to depict the quality of groundwater as well as possible pathways of geochemical evolution. The diagram consists of three well-defined fields: two triangular fields (cation and anion) and a central diamond-shaped field. The overall characteristics of water are represented in the central diamond-shaped field by projecting the position of plots in the triangular fields. The plot shows that alkaline earths $\left(\mathrm{Ca}^{2+}+\mathrm{Mg}^{2+}\right)$ exceed 


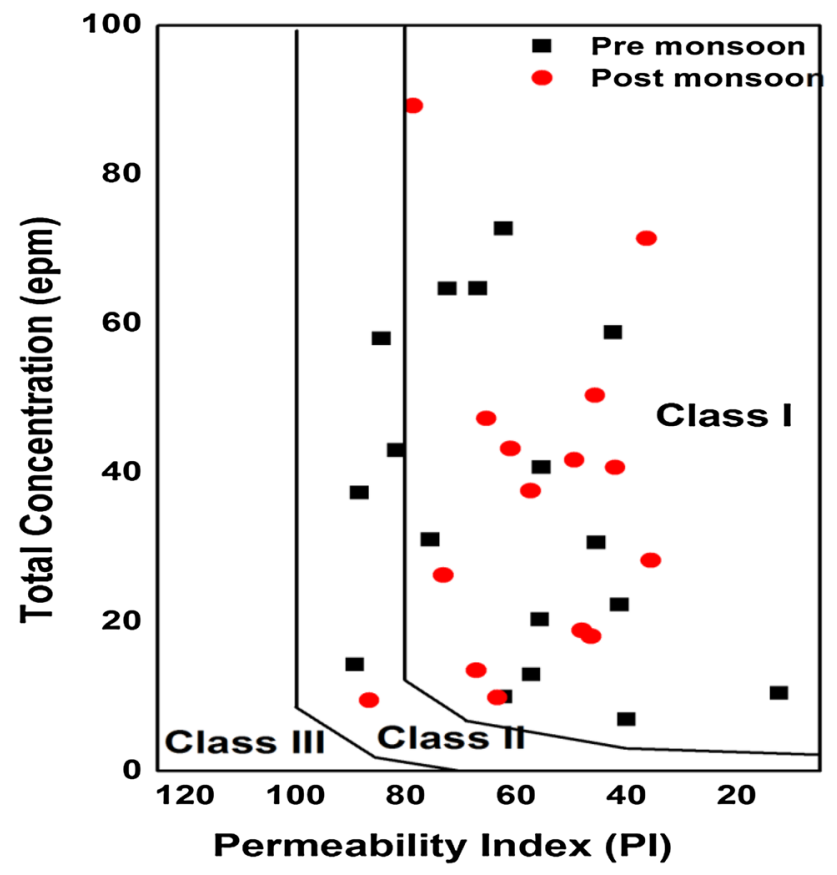

Fig. 7 Permeability index of the groundwater samples of Bathinda district

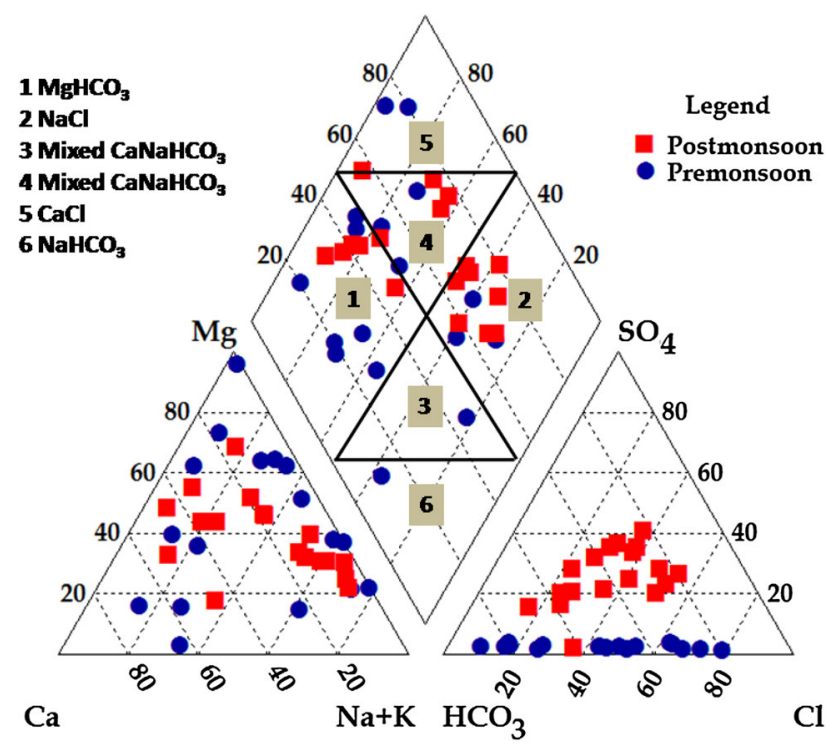

Fig. 8 Piper's trilinear plot of major ion data of groundwater, Bathinda district, Punjab

alkalies $\left(\mathrm{Na}^{+}+\mathrm{K}^{+}\right)$and strong acids $\left(\mathrm{SO}_{4}{ }^{2-}+\mathrm{Cl}^{-}\right)$ exceed weak acids $\left(\mathrm{CO}_{3}{ }^{2-}+\mathrm{HCO}_{3}{ }^{-}\right)$in both the seasons. The major water types present are $\mathrm{Na}-\mathrm{Mg}-\mathrm{Cl}, \mathrm{Na}-\mathrm{Mg}-$ $\mathrm{HCO}_{3}$ and $\mathrm{Mg}-\mathrm{Na}(\mathrm{Ca})-\mathrm{HCO}_{3}$ in the pre-monsoon and $\mathrm{Na}-$ $\mathrm{Mg}-\mathrm{Cl}, \mathrm{Ca}-\mathrm{Mg}-\mathrm{HCO}_{3}$ and $\mathrm{Mg}-\mathrm{Ca}-\mathrm{HCO}_{3}$ in the postmonsoon. A few representations of $\mathrm{Ca}-\mathrm{Na}-\mathrm{Cl}$ are also observed in both the seasons. Overall, the groundwater is dominated by Na-type followed by $\mathrm{Mg}$ and $\mathrm{Ca}$ types. In the case of anions, the groundwater is dominated by Cl-type followed by $\mathrm{HCO}_{3}$ and $\mathrm{SO}_{4}$ types. It can be observed that during post-monsoon, the groundwater tends to become $\mathrm{Na}-\mathrm{Mg}-\mathrm{Cl}$ type from $\mathrm{Mg}-\mathrm{Ca}-\mathrm{HCO}_{3}$ type. This variation in chemical facies can be attributed to dissolution of salts deposited by evapotranspiration of irrigation water and subsequent mixing with groundwater.

$\mathrm{Na}^{+}$is contributed by the interaction of groundwater with silicate minerals as well as evaporite deposits and irrigation return flows. The main sources of $\mathrm{Mg}^{2+}$ are evaporite deposits and also dolomitic rocks. $\mathrm{Ca}^{2+}$ is derived mostly from the carbonate minerals present in the kankar. The geochemical processes responsible for the presence of $\mathrm{SO}_{4}{ }^{2-}$ in groundwater of this district are gypsum dissolution or/and pyrite oxidation. Bicarbonate concentration in groundwater is mostly derived from the bacterial oxidation of organic matter, leaching and dissolution of carbonate rocks. In addition to these natural sources, wastes discharged from the municipal and industrial discharges also contaminate the groundwater resources.

The major ion data of the groundwater is also commonly interpreted using Chadha's plot by many researchers (Herojeet et al. 2013; Kumar et al. 2009; Singh et al. 2011; Thakur et al. 2016; Thilagavati et al. 2012). This plot is constructed by plotting the difference in milliequivalent percentage between alkaline earths and alkali metals, expressed as percentage reacting values, on the $X$-axis; and the difference in milliequivalent percentage between weak acidic anions and strong acidic anions, also expressed as percentage reacting values, on the $Y$-axis. The milliequivalent percentage differences from the $X$ and $Y$ co-ordinates are extended further into the main study subfields of the proposed diagram, which defines the overall character of water. The hydrochemical processes suggested by Chadha (1999) are indicated in each of the four quadrants of the graph. Field-1 represents $\mathrm{Ca}-\mathrm{HCO}_{3}$ type of recharging waters, Field-2 represents $\mathrm{Ca}-\mathrm{Mg}-\mathrm{Cl}$ type of reverse ionexchange waters, Field 3 represents $\mathrm{Na}-\mathrm{Cl}$ type of endmember waters (seawater) and Field 4 represents $\mathrm{Na}-$ $\mathrm{HCO}_{3}$ type of base ion-exchange waters.

From the diagram (Fig. 9), it can be seen that most of the groundwater samples of pre-monsoon season fall in Field 2 and 3, but in Field 1 and 3 during post monsoon. Samples from both seasons mostly fall in Field 2 depicting reverse ion exchange as the main geochemical process modifying the water type of groundwater. In post-monsoon, the rainwater contribution leads to the formation of $\mathrm{Ca}-\mathrm{HCO}_{3}$ type recharging water, which undergoes dissolution of salts from the unsaturated zone at some locations to become $\mathrm{Mg}-\mathrm{Ca}-\mathrm{Cl}$ type of water, which subsequently undergoes ion exchange with the clay zones present in the formation and is modified to $\mathrm{Na}-\mathrm{Mg}-\mathrm{Cl}$ water type. The ion exchange with the clay material can be represented as: 


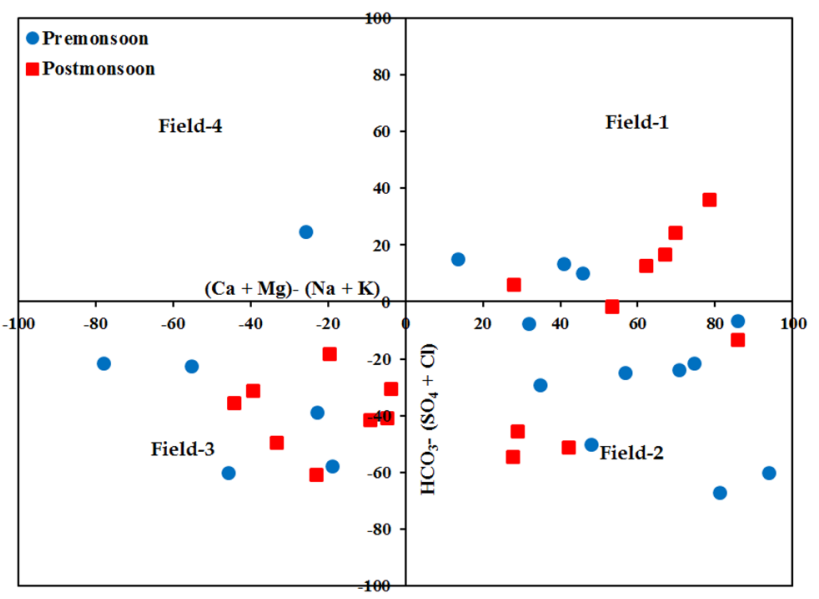

Fig. 9 Chadha's plot of groundwater samples of pre- and postmonsoon seasons, Bathinda district, Punjab

$\mathrm{Na}_{2}$-Clay $+\mathrm{Ca}^{2+} \rightarrow \mathrm{Ca}^{2+}$-Clay $+2 \mathrm{Na}^{+}$

One sample in pre-monsoon period falls in Field 4 which could be probably due to dissolution of halite from the evaporite minerals. In rest of the cases, pre-monsoon samples are mostly affected by mineral dissolution or ion exchange process. Since this is a semi-arid region, evaporation is higher than the precipitation, this renders accumulation of salts in the unsaturated zone. In addition to this, excess irrigation raises the water table to within $2 \mathrm{~m}$ of soil surface through capillary action, this coupled with poor percolation due to impervious strata, application of excessive fertilizers, restricted soil drainage and changes in cropping pattern lead to salinization of the shallow waters of this region. The groundwater evolution of this district can be broadly depicted as follows (Fig. 10).

\section{Conclusion}

In this paper, the suitability of groundwater in Bathinda district was evaluated for drinking and irrigation. Geochemical processes affecting the groundwater chemistry were also evaluated using Piper's trilinear and Chadha's plots. The effect of monsoon on local groundwater system was studied by comparing the chemistry of pre- and postmonsoon samples. Results indicate that among different hydrochemical parameters, $\mathrm{F}^{-}, \mathrm{Mg}^{2+}, \mathrm{SO}_{4}{ }^{2-}, \mathrm{TH}, \mathrm{NO}_{3}{ }^{-}$ and $\mathrm{HCO}_{3}{ }^{-}$were found to be above drinking water permissible limits in most of the samples, whereas contamination by other parameters was marginal. Indicators such as SAR, RSC, Na\% and PI that qualify the water for irrigation were found to be under good to suitable category during pre-monsoon, while doubtful to unsuitable category during post-monsoon season. Presence of high bicarbonate concentration renders water samples to fall under doubtful to unfit category. Geochemical interpretation of the hydrochemical data inferred that $\mathrm{Na}^{+}, \mathrm{Mg}^{2+}$ are major cations followed by $\mathrm{Ca}^{2+}$, while in the case of anions, $\mathrm{Cl}^{-}, \mathrm{HCO}_{3}{ }^{-}$ are dominant followed by $\mathrm{SO}_{4}{ }^{2-}$. During pre-monsoon, the groundwater was mainly affected by dissolution of minerals and ion exchange processes, while in post-monsoon, rainwater laden with salts from the unsaturated zone also contributed to the local groundwater. A geochemical schematic diagram is established based on Piper trilinear and Chadha's classifications of groundwater. Leaching of salts in the unsaturated zone, contribution of soluble fertilizers and livestock excrement play a significant role in contaminating the shallow aquifers of this district. This study is significant as the surface water resources are limited and the quality and quantity of groundwater are deteriorating due to anthropogenic activities.
Fig. 10 Schematic representation of geochemical evolution of groundwater, Bathinda district

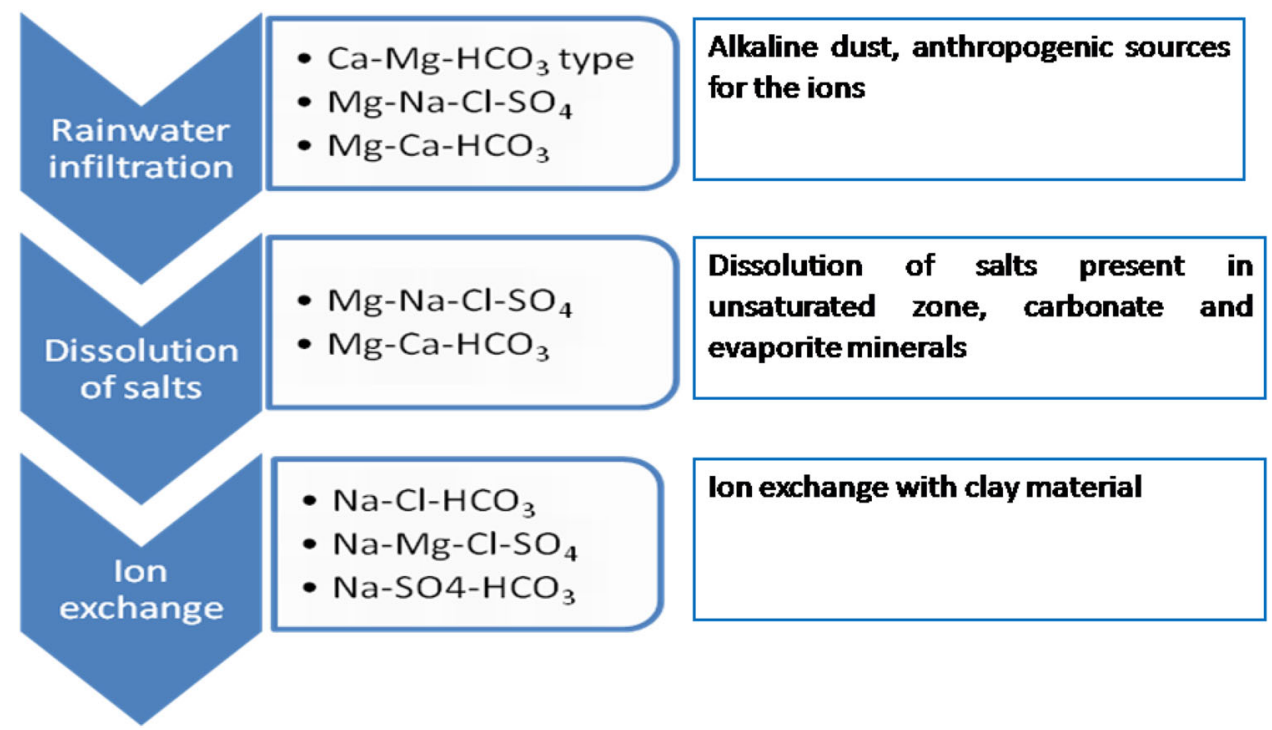


Acknowledgments The authors would like to acknowledge the Board of Research in Nuclear Sciences, Department of Atomic Energy, Government of India for providing the necessary financial support to carry out this work (Letter No. 35/14/11/2014-BRNS-193). Authors would also like to express special thanks to Mr. Kuldeep, Lab technician, Department of Geology for his help and cooperation during the analysis. Authors also like to acknowledge the support and encouragement by Dr. Uday Kumar Sinha, Head, Isotope Hydrology Section, Isotope Production and Applications Division, Bhabha Atomic Research Centre, Mumbai.

Open Access This article is distributed under the terms of the Creative Commons Attribution 4.0 International License (http:// creativecommons.org/licenses/by/4.0/), which permits unrestricted use, distribution, and reproduction in any medium, provided you give appropriate credit to the original author(s) and the source, provide a link to the Creative Commons license, and indicate if changes were made.

\section{References}

APHA (1998) Standard methods for the examination of water and wastewater, 19th edn. APHA, Washington

Bhattacharya P, Ramanathan AL, Mukherjee AB, Bundschuh J, Chandrasekharam D, Keshari AK (2008) Groundwater for sustainable development: problems, perspectives and challenges. CRC Press, Boca Raton

BIS (2012) Indian standards specification for drinking water. IS:10500:2012, 2nd Rev, BIS, New Delhi

Central Ground Water Board (CGWB) (2007) Ground Water information booklet. Bathinda District, Punjab, North Western Region, Chandigarh

Central Ground Water Board (CGWB) (2013) Report on dynamic groundwater resources of Punjab state (as on March 2011). Central Groundwater Board, North Western Region, Chandigarh, pp $1-135$

Central Ground Water Board (CGWB) (2014) Groundwater year book Punjab and Chandigarh. Northwestern region, Chandigarh, India

Chadha DK (1999) A proposed new diagram for geochemical classification of natural waters and interpretation of chemical data. Hydrogeol J 7(5):431-439

Chatterjee A, Roy RK, Ghosh UC, Pramanik T, Kabi SP, Biswas K (2008) Fluoride in water in parts of Raniganj coalfield, West Bengal. Curr Sci 94:309-311

Chopra RPS, Krishan G (2014) Assessment of groundwater quality in Punjab, India. Earth Sci Clim Change 5:10. doi:10.4172/21577617.1000243

David MD, Gentry LE (2000) Anthropogenic inputs of nitrogen and phosphorus and riverine export for Illinois, USA. J Environ Qual 29:494-508

Davies SN, DeWiest RJM (1966) Hydrogeology. Wiley, New York

Doneen LD (1964) Notes on water quality in Agriculture. Published as a Water Science and Engineering, Paper 4001, Department of Water Sciences and Engineering, University of California

Durfor CN, Becker E (1964) Public water supplies of the 100 largest cities in the United States. Water supply paper No. 1812, pp 343-346

Geological Survey of India (GSI) (1976) Know your district Bathinda (Punjab). 125th Anniversary celebrations, Geological Survey of India

Hem JD (1991) Study and interpretation of the chemical characteristics of natural waters. Book 2254, 3rd edn. Scientific Publishers, Jodhpur, p 263
Herojeet RK, Rishi MS, Sidhu N (2013) Hydrochemical characterization, classification and evaluation of groundwater regime in Sirsa Watershed, Nalagarh Valley, Himachal Pradesh, India. Civil Environ Res 3(7):47-57

Hitchon B, Perkins EH, Gunter WD (1999) Introduction to groundwater geochemistry. Geoscience Publishing Ltd., Alberta

Hounslow AW (1995) Water quality data analysis and interpretation. CRC Press, Florida

Karanth KR (1987) Groundwater assessment, development and management. Tata-McGraw-Hill, New Delhi

Keesari T, Shivanna K, Jalihal AA (2007) Isotope hydrochemical approach to understand Fluoride release into groundwaters of Ilkal Area, Bagalkot District, Karnataka, India. Hydrogeol J 15:589-598

Keesari T, Kulkarni UP, Deodhar A, Ramanjaneyulu PS, Sanjukta AK, Kumar US (2014) Geochemical characterization of groundwater from an arid region in India. Environ Earth Sci 71(11):4869-4888

Kochhar N, Gill GS, Tuli N, Dadwal V, Balaram V (2007) Chemical quality of groundwater in relation to incidence of cancer in parts of SW Punjab, India. Asian J Water Environ Poll 4(2):107-112

Krishan G, Rao MS, Kumar CP, Semwal P (2013) Identifying salinization using isotopes and ion chemistry in semi-arid region of Punjab, India. J Geol Geosci 2:4. doi:10.4172/jgg.1000129

Kumar M, Kumari K, Singh UK, Ramanathan AL (2009) Hydrogeochemical processes in the groundwater environment of Muktsar, Punjab: conventional graphical and multivariate statistical approach. Environ Geol 57:873-884

Lloyd JW, Heathcote JA (1985) Natural inorganic hydrochemistry in relation to groundwater. Clarendon, Oxford, p 294

McCarthy MF (2004) Should we restrict chloride rather than sodium? Med Hypotheses 63:138-148

Mittal S, Arora SK (2014) A study of evaluation of groundwater quality of Bathinda region of Punjab. Int J Eng Inn Technol 4(1):149-154

Piper AM (1944) A graphical procedure in the geochemical interpretation of water analysis. Trans Am Geophys Union 25:914-928

Punjab Water Resources and Environment Directorate (PHRED) (2014) Status on groundwater quality in Punjab. A report based on PDS HP-II project, HG-WR (201), Chandigarh

Ramakrishna (1998) Groundwater handbook. India

Ramanathan AL, Bhattacharya P, Keshari AK, Bundschuh J, Chandrasekharam D, Singh SK (2009) Assessment of groundwater resources and management. IK International Publishing House Pvt. Ltd., New Delhi, pp 1-501

Ray SK, Gosh S, Nagchauduri J, Tiwari IC, Kaur P (1981) Prevalence of fluorosis in rural community near Varanasi. Fluoride 14:86-90

Richards LA (1954) Diagnosis and improvement of saline and alkali soils. US Department of Agriculture, Agri. Hand book 60, Washington

Sidhu N, Rishi MS, Herojeet RK (2013) Groundwater quality variation with respect to aquifer dispositioning in urbanized watershed of Chandigarh, India. Int J Environ Ecol Family Urban Stud 3(2):87-98

Singh K, Hundal HS, Singh D (2011) Geochemistry and assessment of hydrogeochemical processes in groundwater in the southern part of Bathinda district of Punjab, northwest India. Environ Earth Sci 64:1823-1833

Thakur T, Rishi MS, Naik PK, Sharma P (2016) Elucidating hydrochemical properties of groundwater for drinking and agriculture in parts of Punjab, India. Environ Earth Sci 75:467-471

Thilagavati R, Chidambaram S, Prasanna MV, Thivya C, Singaraja C (2012) A study on groundwater geochemistry and water quality 
in layered aquifers system of Pondicherry region, southeast India. Appl Water Sci 2:253-269

Todd DK (1980) Ground water hydrology. Wiley, New York

Tripathi SD, Aravindakshan PK, Ayyappan S, Jena JK, Muduli HK, Suresh C, Pani KC (2000) New high in crop production in India through intensive polyculture. J Aqua Trop 15:119-128

Trivedy RK, Goel PK (1984) Chemical and biological methods for water pollution studies. Environmental Publication, Karad

USSL (1954) Diagnosis and improvement of saline and alkaline soils. United States Salinity Laboratory, US Department of Agriculture, Washington
WHO (2011) Guidelines for drinking water quality. World Health Organization, Geneva

Wilcox LV (1948) The quality of water for irrigation use. U.S. Department of Agriculture, Tech Bull 962, Washington, pp 1-40

Wilcox LV (1955) Classification and use of irrigation water. US Department of Agriculture, Washington, p 969 